Original Research

\title{
Factors Influencing Mothers' Intention to Immunize Children Younger than Five Years of Age in West Borneo: a Cross-Sectional Study
}

\section{Setho Hadisuyatmana1, Ilya Krisnana1, Muhammad Adil Sipahutar2}

1 Faculty of Nursing, Universitas Airlangga, East Java, Indonesia

2 Health Office of Pontianak

\begin{abstract}
Introduction: Immunisations for BCG, DTP, Poliomyelitis, Hepatitis, and MMR are compulsory for children under 5 years old in Indonesia and government-provided free services. However, the available records indicated that adherence to the program remains a challenge. This study aimed to investigate factors associated with mothers' intention to comply with the immunization program, particularly among those who had children of younger than one year old.
\end{abstract}

Methods: The study was conducted through a cross-sectional analysis. Fourty-six mothers self-registered them selves as participants of this study. The data were collected through check-listed interviews, to investigate the correlations between social factors, information factors, attitude toward behaviour, subjective norm, perceived behavioural control, and intention to adhere to the compulsory immunization program. The data were then analysed using logistic regression and spearman rank test with significance level of $\alpha=0.05$.

Results: Mothers' attitude, subjective norm, perceived behavioral control, and knowledge have significant correlations with the intention in completing the immunisation program for their children (respectively $\mathrm{p}=0.009 ; 0.014 ; 0.025$; 0.038). Their intention positively correlated with adherence to complete the program $(\mathrm{p}=0,002)$. However, other factors studied did not correlate either with mothers' intention to adherence to the program.

Conclusion: This study suggests that mothers' intention is influenced by family members suggestions, indicating that their capacity in decision making was limited and relying to other member. Further investigation is required to unveil the underlying reasons of being non-adherence.

\section{ARTICLE HISTORY}

Received: August 16, 2018

Accepted: Sept 09, 2019

\section{KEYWORDS}

ICU; children; immunization compliance; intention; mother

\section{CONTACT}

Setho Hadisuyatmana $\triangle$ setho.h@fkp.unair.ac.id $\equiv$ Faculty of Nursing, Universitas Airlangga, East Java, Indonesia

Cite this as: Hadisuyatmana, S., Krisnana, I., Sipahutar, M.A. (2019 Factors Influencing Mothers' Intention to Immunize Children Younger than Five Years of Age in West Borneo: a Cross-Sectional Study. Jurnal Ners, 14(1),41-46. doi:http://dx.doi.org/10.20473/jn.v14i1.9406

\section{INTRODUCTION}

Immunisations for BCG, DTP, Poliomyelitis, Hepatitis, and MMR are compulsory in Indonesia to protect children younger than 5 years old from contracting the diseases (Kemenkes RI 2016). This program is provided as a free-paid service in public hospitals and public health centers (known as Puskesmas). Otherwise, mothers have to access it under an out-ofpocket service in private practitioners. The success of a $100 \%$ compliance is expected to prevent outbreaks and premature deaths among the children (Destiyanta et al. 2015). The government of Indonesia has set a target of $100 \%$ immunization rate as the success indicator. Nevertheless, only $82.30 \%$ of the targeted children complied the program (Kemenkes RI 2016). This indicates that the program was yet successfull.

The available literature admited that adherence to immunization remains a challenging issue all over the world. Like in the United States of America, parental religious perspective had pushed 17 states to allow a philosophical exemption towards compulsory immunization program (Womack, 2010). Another issues raised in low and middle income countries (LMICs) such as in India and Lao (Phimmasane et al., 2010, Masand et al., 2012). These studies reason the parental knowledge around the necessity of immunization and their low social-economic capacity as major hindrance to the non-compliance behaviour. 
The World Health Organization (WHO 2015) supported that the similar cases in 2014 had caused over 11.3 million children who lived in LMICs unable to access health services for vaccination. The WHO asserts that the situation is responsible for more than two million of premature deaths in these countries. Therefore, the organization (2015) prioritizes $100 \%$ coverage of immunization program in LMICs, including Indonesia. However, it was reported that more than $32.1 \%$ of children in Indonesia failed complete the compulsory program, and more than $13.5 \%$ others were never immunized (Kementerian Kesehatan Republik Indonesia 2013).

Particularly in Pontianak, the capital city of West Borneo, there were more than $27.58 \%$ of the babies did not comply to the immunization program during 2015 (Dinkes Kota Pontianak 2016). The Puskesmas of Siantan Tengah, one of the public health centers in the city, reported that there were only $50.2 \%$ of the babies accessed to get the immunization. This reasoned the outbreaks of diphtheria, neonatal tetanus, Measles, and Hepatitis B. Local investigation informed that none of these children complied with the program (Dinkes Kota Pontianak 2016). On the other hand, it is reported that a mother's lack-ofawareness toward health significantly contributed to the situation (Satgas IDAI 2011). Adekeye et al. (2015), Barkun (2012), Febriastuti et al. (2014) and Rizani et al. (2009) agreed that this could also be influenced by mothers' personal attitude and past experience about immunization. Harmasdiyani (2015) added that family support, level of education, and the accessibility of health service also determined the compliance toward the program.

Ajzen's Planned Behaviour Theory (2005) offers a way to further understand this phenomenon. It explains that intention, attitude or valuation, and perceptions on social norm could affect one's behavior. Particular to the studied phenomenon, this theory lends a light to explain the underlying factors (Uddin et al. 2012). The behavior belief refers to an individual's notion toward the results of acts (belief strength) and its evaluation (outcome evaluation). The normative belief refers to expectations toward other's expectation, and a personal motivation to fulfill the expectations, while control belief adresses the accessibility of supports against attempts to bring out the intention into action (Nursalam 2013). This study aimed to examined factors that influenced mothers' intention to immunize their children of younger than one year old.

\section{MATERIALS AND METHODS}

\section{Research Design}

This study targeted at 178 mothers of babies aged ranging from 9 to 12 months old in the work area of a public health center (Puskesmas) in Pontianak, West Borneo, as population. We selected the sample purposively following inclusion criteria: have at least one child who were currently aged between 9-12 months old, registered in the monthly screening cohort, literate, and have the mother and child health manual book that were government-provided. We approached targeted mothers when they were coming for a routine check for their babies, provided information regarding the study, and offer them written consents upon their agreement. Mothers who were registered as regular clients of the Puskesmas and owned a mother and child health manual book, were offered as participants in this study.

This study was conducted under the light of crosssectional approach, where by we examined the correlations between participants social factors (age, gender, education, ethnicity, income, and religious belief), information (experience, knowledge, and media exposure), attitude, subjective norm, and perceived behavior control and their intention and the adherence to immunization program. The predictors were investigated using a questionnaire adapted from Ajzen's (2006) Planned Behavior questionnaire that has been translated and validated in Jerman, Amerika, Italia, Uganda, China (Adekeye et al. 2015). We use the Bahasa Indonesia version developed by and tested for validity and reliability by Febriastuti, Arif, \& Kusumaningrum (2014). The questionnaire used in this study was originally designed to collect non-continuous data. Participants' intention and the adherence to immunization program were identified using the nationalstandardized mother and child health manual book. A verbal permission was granted from Kusumaningrum (Febriastuti, Arif, \& Kusumaningrum 2014) through a phonecall. The validity and reliability issues of questionnaires used in this study have been evaluated by the original authors. The validity test used $r$ table $=0.561$ using the significance level of $95 \%$ resulted the score of $0.816-0.915$ for all the questions. The reliability of the questionnaire was tested using Cronbach's alpha resulted the score of 0.975 .

\section{Data Collection and Analysis}

We collected the data between October-December 2016, at one of the Puskesmas in the region of Siantan Tengah, the province of West Kalimantan. The questionnaire was distributed to participating mothers, following written consent. Each mother was given time to look the given questionaires and provided assistance if required to guide in filling up the questions. The data collection process was conducted afte the mothers finished meeting with the doctor. We provided chairs and table and utensils for mothers to fill questionnaire sheet. Souvenirs equal to 100.000 Indonesian Rupiah were distributed after the data collection process or for those who decided not to continue their participations. The collected data were then cleaned and analysed using univariate, bivariate, and multivariate modes of analysis Spearman Rank's Test using the significant level of $\alpha<0.05$. A logistic regression was employed to examine the interrelationship of multiple independent variables (social, information, attitude, 
subjective norm, and perceived behavior factors) and mothers' intention to adhere to the immunization program. These multivariate analyses were tested using the significant level of $\alpha<0.05$.

\section{Ethical Consideration}

The Universitas Airlangga's Human-Health Research Ethical Committee has approved this study under the article number 267-KEPK.

\section{RESULTS}

\section{Demographic Details}

A total of 46 mothers were voluntarily participating in this study. Most of the participating mothers were younger than 21 years old (50\%) and graduated from primary school (39.1\%), indicating that they might lacked education. They were mostly lived in poorly financial-support (71.7\%) and coming from Madura as cultural background (54.3\%) (see Table 1). Most participants relied on the Puskesmas as the main source of information in relate with the immunization program (93.5\%), while the electronic-based and printed media were less likely accessed. The majority of the participants (54.3\%) have sufficient knowledge about the necessity of the compulsory immunizations for their children (see Table 2).

\section{Attitude, Subjective Norm, and Perceived Behavioural Control toward Immunization Program}

In regard to attitude, more than half of participants $(56.5 \%)$ refused to follow the program, and about $43.5 \%$ of the others were being supportive. In term of their subjective norm, $56.5 \%$ of participants ignored the supports from their immediate family, friends, and health personnel. The majority of participants (63\%) have poor perception toward the immunization program, only about $28.3 \%$ of mothers viewed the program positively. Most mothers (60.9\%) have low intention to follow the immunization program. Respectively, most children younger than five years of age $(56.5 \%)$ failed to comply with the compulsory immunization program (see Table 3).

\section{The Interrelationship of Age, Education Background, Household Income, Religious View, Ethnic, Past Experience, Media Exposure, and Intention to Adhere the Compulsory Immunization Program}

The findings in this study show that age, the highest level of education, family income, religious view, ethnical background, personal past experience, and media exposure have no correlation with participants' intention to adhere to the program despite the odds ratio inform significant figures $(\mathrm{OR}<$ 0.05) (see Table 4).
The Interrelationship between Knowledge, Personal Belief and Family Support, Awareness, and Intention Adhere to the Compulsory Immunization Program

This study suggests that mothers who acquired sufficient understandings about the significance of immunization have higher intention to access Puskesmas on behalf of their children $(p=0.038)$ when compared with their counterparts (see table 5). The odd ratio of this variable indicates that acquired knowledge on immunization would improve the probability of mothers being adhered to the program by 3.127 times higher.

The regression analysis suggests that mothers' attitude toward immunization has a significant interrelation with their intention to follow the program $(p=0.009)$ The odd ratio of this correlation indicates that mothers' belief toward the result of immunization contributes as many as 8.037 times higher to influence their adherence to the immunization program (see table 5). Likewise, supports from immediate families inclucing husbands and parents (subjective norm) also strengthen participants' intention to immunize their children (logistic regression test of $\mathrm{p}=0.014$, with its odd ratio of 5.056).

Additionally, all of the aforementioned factors also determine mothers' awareness toward the importance of immunizations for their children. As the regression test shows that the awareness (perceived behaviour control) has a close interrelationship with mothers' intention to adhere to the immunization program $(\mathrm{p}=0.025, \mathrm{OR}=0.445)$.

The analisys of the results suggest that mothers' intention correlates with childrens' completion in following the compulsory immunization provided by the Indonesian government. The spearman rank test ( $p$ of 0.002 ) infers that the higher the mother intention the higher possibility of children's compliance to the immunization program.

\section{DISCUSSION}

The findings in this study showed that the majority of the participants gave birth at a young age with low level of education, and half of the children were not completely immunized. This study also finds a strong and positive correlation between mothers' level of understanding and intention to comply the children's compulsory immunization program. Ajzen (2005) lends a support to this finding and reasons the low participation in the compulsory immunization program as a result from mothers' insufficient knowledge. This leads to a notion that the low understanding and awareness among mothers determines the low adherence, as well as negative perception towards the program (Gustin, 2012). This indicates that participants' poor perception and rejection to adhere with the program were most likely as a result from their unfamiliarity on the importance of immunization for their children. However, the current study argues that there is no significant 
correlation between mothers' age, level of formal education, and intention to comply with the program. Also, this rejects prior finding by (Kusnanto et al., 2017), whereby the authors underscored the highest level of formal education as a determinant in baby's immunization status. Instead, this study implies that mothers' knowledge on children's immunization was not determined by their young age and low level of formal education. Rather, they may be non-formally exposed by different source of information, which is yet explored in this study. The positive and strong correlation between attitude and intention shown in this study indicate that good understanding is fundamental for mothers whose children need to be immunized.

Another finding in this study infers the local public health centre (Puskesmas) is viewed as the most reliable and accessible source of information regarding the immunization program. The participants heavily relied to the Puskesmas to gain important updates regarding the program. Participants who acquired sufficient understandings about the significance of immunization have higher intention to access the Puskesmas when compared with their counterparts. This finding underscores the role of Puskesmas in promoting immunization program to mothers (Mulyanti, 2014). However, this did not guarantee that they would comply with the program, despite the finding suggest that mothers' awareness has a strong correlation with their intention to adhere to the program.

The finding indicates that most participants could only access Puskesmas for an immunization provider due to their low economic background. Most participants lived under the insufficient household income, lower than the regional minimum wage of US\$ 150 per month (Sulistiawati, 2013). Thus, it is unlikely that they would spend out-of-pocket money to get the immunization from private health practices. This suggests that being absence in a Puskesmasscheduled immunization was a non-adhere behavior (Puspitaningrum 2015), otherwise program's misinformation or other possible causes that have not been explored under this study. This finding suggests further investigation on the underlying reasons of being non-adherence, given the free services by local Puskesmas and mothers good knowledge around children immunization.

The strong correlation between family supports and intention found in this study implies that mothers' intention to immunize children is strongly influenced by supports given by families (including husbands, parents, or peer). In further analysis, positive correlation is found between mothers' intention and children compliance to immunization program. This raises the significant role of family members as determinant for children's immunization status and rate improvement. This study informs that there is a tendency among participants to have higher intention in following the program, with regard to the positive supports given by family members, including parents and siblings and husbands. This finding lends a support to earlier studies by Ismet (2013) and Sarimin, Ismanto \& Worang (2014), whereby the authors underscored the necessary of supports from immediate parents and siblings. This finding further suggests the necessity to involve family members as a strategy to improve children immunization rate. This indicates that mothers' intention is more a result of cumulative thought than sole decision.

However, one study showed that women's inferiority in family decision-making significantly contributes to the non-compliance behaviour in regards to children immunization program (Afriani et al., 2014) that lead to failure in completing the compulsory immunizations (Puspitaningrum 2015). This can be another reason to the non-adhere behaviour among mothers and low rate of immunization. However, this remains unclear and requires future studies in attempt to unveil the best strategy in improving children immunization rate.

\section{CONCLUSION}

This study finds that mothers' age, education background, ethnics and religion, and perspective did not play roles to children immunization rate. Rather, there is an indication that mothers were unable to comply by themselves due to the interplay in family decision-making. Therefore, it is suggested that family members within or those influencing the household need to be involved in health promotions, particularly to improve the immunization rate. However, these results can only be generalized to mothers lived in the area of Siantan Tengah, one region in the province of West Kalimantan.

The limitations of this study are around the questionnaire details and the number of mothers as participants. The age of participants when first become a mother was not asked; this raised a loose argument to imply that the participants were novice to the immunization program. Secondly, the small number of participants in this study informs that the finding should be generalized with considerate manner. This study, however, adds new evidence and suggests a further study to involved families in investigating their roles to children immunization rate and uptake.

\section{ACKNOWLEDGE}

Prof Eileen Savage RGN who contributed in her kind assistance to review this article for submission.

\section{REFERENCES}

Adekeye, O.A., Chenube, 0.0. \& Adekeye, B.T., 2015. Knowledge , Attitude and Barriers towards Children Immunization among Women in Selected Rural Primary Health Centres Fred Ahmadu. Ife PsycholoIA, 23(1), pp.89-97.

Afriani, T., 2009. Kelengkapan Imunisasi Dasar Anak Balita dan Faktor-Faktor yang Berhubungan di Poliklinik Anak Beberapa Rumah Sakit di Jakarta 
dan Sekitarnya pada Bulan Maret 2008. Buletin Penelitian Sistem Kesehatan, 11(1), pp.1-7. DOI: http://dx.doi.org/10.14238/sp11.1.2009.1-7

Afriani, T., Andrajati, R. \& Supardi, S., 2014. FaktorFaktor Yang Berhubungan Dengan Kelengkapan Imunisasi Dasar Pada Anak Dan Pengelolaan Vaksin Di Puskesmas Dan Posyandu Kecamatan X Kota Depok. Buletin Penelitian Sistem Kesehatan, 17(2), pp.135-142.

Ajzen, I., 2005. Attitudes, Personality And Behavior second., Buckingham: Open University Press. Ajzen, I., 2006. Contructing a TPB Questionnaire: Conceptual and Metodological Considerations. september., Buckingham: Open University Press, Milton Keynes.

Anggraeni, D., 2013. Hubungan perilaku ibu mengimunisasikan DPT dengan status kelengkapan imunisasi dpt dasar pada bayi usia 11 bulan di Kesa Kaliwates Kecamatan Kaliwates Kabupaten Jember. Universitas Jember.

Arumsari, D.R., 2015. Fakto-Faktor Yang Berhubungan dengan Status Imunisasi Dasar pada Bayi. Jurnal STIK Maharani Malang, 3(6), pp.7688. DOI: $10.33085 / j k g . v 1 i 3.3955$

Azwar, S., 2010. Sikap Manusia Teori dan Pengukurannya, Yogyakarta: Pustaka Pelajar.

Babirye, J.N. et al., 2011. More support for mothers : a qualitative study on factors affecting immunisation behaviour in Kampala, Uganda. BMC Public Health, 11(1), p.723. doi: 10.1186/1471-2458-11-723

Barkun, A.L., 2012. Imunisasi 2nd ed., Jakarta: Balai Penerbit FKUI.

Burke S, D. et al., 2011. Protecting the Frontline in Biodefense Research the Special Immunizations Program Fifth., Washington, DC: The National Academies Press. https://doi.org/10.17226/13112.

Conis, E., 2015. Vaccine Nation, America's Changing Relationship with Immunization, Chicago and London: The University of Chicago Press.

Destiyanta, A.P., Kusumawati, Y. \& Catur, A.W., 2015. Hubungan Tingkat Pendidikan, Pekerjaan dan Pengetahuan Ibu dengan Ketepatan Jadwal Mengikuti Imunisasi Campak di Wilayah Kerja Puskesmas Weru Sukoharjo. Jurnal FIK UMS, 3(6), pp.78-90.

Dharma, K.K., 2011. Metodologi Penelitian Keerawatan (Pedoman Melaksanakan dan Menrapkan Hasil Penelitian), Jakarta: Trans Info Media.

Dinkes Kota Pontianak, 2016. Profil Kesahatan Kota Pontianak R. Mustika, I. Rossa, \& Fakhurrozi, eds., Pontianak: Dinas Kesehatan Kota Pontianak.
Fajriyah, I., 2014. Hubungan pengetahuan ibu dan dukungan keluarga dengan status imunisasi td pada sub pin difteri. Jurnal Berkala Epidemiologi, $2(3)$, pp.404-415. http://dx.doi.org/10.20473/jbe.V6I22018.103111

Febriastuti, N., Arif, Y.S. \& Kusumaningrum, T., 2014. Kepatuhan Orang Tua Dalam Pemberian Kelengkapan Imunisasi dasar pada bayi 4-11 Bulan. Jurnal Ners Unair, 3(31), pp.45-52. http://dx.doi.org/10.20473/pmnj.v2i2.11793

Gustin, R.K., 2012. Hubungan Pengetahuan dan Sikap Tentang ImunisasiTerhadap Pemberian Imunisasi Dasar Lengkap pada Balita di Wilayah Kerja Puskesmas Malak Kabupaten Agam. Jurnal Kesehatan Stikes Prima Bukittinggi, 3(2), pp.1016.

Harmasdiyani, R., 2015. Pengaruh karakteristik ibu terhadap ketidakpatuhan pemberian imunisasi dasar lengkap pada anak bawah dua tahun. Jurnal Berkala Epidemiologi, 3(3), pp.304-314. DOI: 10.20473/jbe.v6i12018.86-94

Irawati, D., 2011. Faktor Karakteristik Ibu yang Berhbungan dengan ketepatan Imunisasi DPT Combo dan Campak di Pasuruan. Hospital Majapahit, 3(1), pp.1-14.

Ismet, F., 2013. Analisis Faktor-faktor yang Berhubungan Dengan Imunisasi Dasar Lengkap pada Balita di Desa Botubarani Kecamatan Kabila Bone Kabupaten Bone Bolango. Universitas Negeri Gorontalo, 1(1), pp.4-24.

Kemenkes RI, 2013. Penyelenggaraan Imunisasi, Jakarta: Kementerian Kesehatan Republik Indonesia.

Kemenkes RI, 2013. Riset Kesehatan Dasar, Jakarta: Kementerian Kesehatan RI.

Kemenkes RI, 2015. Panduan Pekan Imunisasi Sedunia Tahun 2015, Jakarta: Kementerian Kesehatan Republik Indonesia.

Kemenkes RI, 2016. Profil Kesehatan Indonesia Tahun 2015, Jakarta: Kementerian Kesehatan Republik Indonesia.

Kusnanto, K., Ulfiana, E. \& Hadarani, M. 2017. Behavior of Family in Practice Hepatitis B Immunization at Baby 0-7 Days Old. Jurnal Ners, 3, 151-156. doi.org/10.20473/jn.v3i2.4998

Maramis, W.F., 2006. Ilmu Perilaku Dalam Pelayanan Kesehatan, Surabaya: Airlangga University Press.

Masand, R., Dixit, A. M. \& Gupta, R. K. 2012. Study of immunisation status of rural children (12-23 months age) of district Jaipur, Rajasthan and factors influencing it: a hospital based study. Journal of the Indian Medical Association, 110, 795799. 
Mohamud, A.N. et al., 2014. Immunization coverage of 12 - 23 months old children and associated factors in Jigjiga District , Somali National Regional State , Ethiopia. BMC Public Health, 14(1), pp.1-9. doi: 10.1186/1471-2458-14-865.

Mulyanti, Y. 2014. Faktor-faktor internal yang berhubungan dengan kelengkapan imunisasi dasar balita usia 1-5 tahun di Wilayah Kerja Puskesmas Situ Gintung Ciputat tahun 2013.

Ningrum, E.P. \& Sulastri, 2008. Faktor-Faktor Yang Mempengaruhi Kelengkapan Imunisasi Dasar Pada Bayi di Puskesmas Banyudono Kabupaten Boyolali. Berita Ilmu Keperawatan ISSN 19792697, 1(1), pp.7-12.

Notoatmodjo, S., 2010. Ilmu Perilaku Kesehatan, Jakarta: PT Renika Cipta.

Nursalam, 2013. Metodologi Penelitian Ilmu Keperawatan: Pendekatan Praktis edisi 3., Jakarta: Salemba Medika.

Phimmasane, M., Douangmala, S., Koffi, P., Reinharz, D. \& Buisson, Y. 2010. Factors affecting compliance with measles vaccination in Lao PDR. Vaccine, 28, 6723-6729. doi: 10.1016/j.vaccine.2010.07.077

Puspitaningrum, 2015. Hubungan tingkat pengetahuan dengan kepatuhan ibu dalam pemberian imunisasi pentavalen di wilayah kerja UPTD Puskesmas Gilingan Surakarta. Stikes Kusuma Husada, 2(1), pp.6-19.

Rahmawati, A.I. \& Umbul, C.W., 2014. Faktor Yang Mempengaruhi Kelengkapan Imunisasi Dasar di Kelurahan Krembangan Utara. Jurnal Berkala Epidemiologi, 1(4), pp.59-70.

Rhamadhani, R.B., 2013. Faktor-faktor Yang berhubungan dengan Kelengkapan Imunisasi Dasar Balita di Desa Balegondo Kecamatan Ngariboyo Kabupaten Magetan. Jurnal FIK UMS, 2(3), pp.18-26.

Rizani, A., Hakimi, M. \& Ismail, D., 2009. Hubungan Pengetahuan, Sikap dan Perilaku Ibu Dalam Pemberian Imunisasi Hepatitis B 0-7 Hari di Kota Banjarmasin. Berita Kedokteran Masyarakat, 25(1), pp.12-20.

Sarimin, S., Ismanto, A.Y. \& Worang, R., 2014. Analisis faktor-faktor yang berhubungan dengan perilaku ibu dalam pemberian imunisasi dasar pada balita di desa Taraitak satu Kecamatan Langowan Utara wilayah kerja Puskesmas Walatakan. Jurnal Universitas Sam Ratulangi Manado, 8(1), pp.20-
28.

Satgas IDAI, 2011. Panduan Imunisasi Anak 1st ed. J. A. Wempi, ed., Jakarta: Badan Penerbit Ikatan Dokter Anak Indonesia.

Satgas Imunisasi IDAI, 2011. Pedoman Imunisasi di Indonesia 4th ed. I. G. G. Ranuh et al., eds., Jakarta: Badan Penerbit Ikatan Dokter Anak Indonesia.

Somantri, A. \& Muhidin, S.Al., 2014. Aplikasi Statistika dalam Penelitian, Bandung: Pustaka Setia Bandung.

Sunaryo, 2013. Psikologi Untuk Keperawatan 2nd ed. B. Bariid, ed., Jakarta: EGC.

Sulistiawati, R. 2013. Pengaruh Upah Minimum terhadap Penyerapan Tenaga Kerja dan Kesejahteraan Masyarakat di Provinsi di Indonesia.

Triana, V., 2016. Faktor yang berhubungan dengan pemberian imunisasi dasar lengkap pada bayi tahun 2015. Jurnal Kesehatan Masyarakat Andalas, 10(2), pp.123-135. DOI: 10.22216/jen.v3i1.2820

Uddin, J. et al., 2012. Improving low coverage of child immunization in rural hard-to-reach areas of Bangladesh : Findings from a project using multiple interventions. Vaccine, 30(2), pp.168179. .doi.org/10.1016/j.vaccine.2011.11.030.

Visser, O. et al., 2016. Intention to Accept Pertussis Vaccination for Cocooning : A Qualitative Study of the Determinants. Plos One, 11(6), pp.1-19. doi: 10.1371/journal.pone.0155861

Wagner, A.L. et al., 2014. Timely measles vaccination in Tianjin, China : a cross-sectional study of immunization records and mothers. BMC Public Health, 14(1), pp.1-7. doi: 10.1186/1471-245814-888.

Weiner, J.L. et al., 2015. Childhood immunizations First-time expectant mothers ' knowledge, beliefs , intentions, and behaviors. Vaccine, 33(9), pp.D92-D98. doi: 10.1016/j.amepre.2015.07.002

WHO, 2015. World Health Statistics 2015 Indicator compendium, New York: World Health Organization.

Wiradharma, D., Rusli, I. \& Wiradarma, K., 2012. Konsep Dasar Vaksinasi K. dr. Wiradarma, ed., Jakarta: Sagung Seto.

Womack, J. M. 2010. Safety and adherence: issues that hinder childhood vaccinations. JAAPA : official journal of the American Academy of Physician Assistants, 23, 42-47. doi: 10.1097/01720610201001000-00010. 